\title{
PENGARUH PEMBERIAN FUNGI MIKORIZA ARBUSKULA DAN PUPUK ORGANIK TERHADAP KANDUNGAN FRAKSI SERAT RUMPUT KUMPAI (Hymenachne amplexicaulis (Rudge) Nees.) PADA ULTISOL
}

\author{
Hardi Syafria 1), dan Novirman Jamarun 2) \\ 1) Program Studi Peternakan Fakultas Peternakan Universitas Jambi \\ 2) Fakultas Peternakan Universitas Andalas. Jl. Limau Manis Padang 25163. \\ Email: hardisyafria@gmail.com
}

\begin{abstract}
ABSTRAK
Fungi mikoriza arbuskula (FMA) dapat membantu tanaman untuk penyediaan dan penyerapan unsur $\mathrm{P}$ yang rendah ketersediaannya pada tanah masam. Pupuk organik dapat memberikan pengaruh terhadap sifat fisik, kimia dan biologis tanah. Tujuan penelitian adalah untuk menemukan, mendapatkan dan membuktikan bahwa perbaikan kesuburan ultisol dengan pemberian FMA dan pupuk organik akan berpengaruh terhadap kandungan fraksi serat rumput kumpai. Percobaan menggunakan Rancangan Acak Kelompok dengan lima macam perlakuan dan 4 ulangan. Perlakuan terdiri dari: 1) FMA o g/rpn + pupuk organik o\%, 2) FMA 20 g/rpn + pupuk organik kotoran sapi 50\%, 3) FMA $20 \mathrm{~g} / \mathrm{rpn}+$ pupuk organik kotoran sapi 100\%, 4) FMA $20 \mathrm{~g} / \mathrm{rpn}+$ kompos 50\%, dan 5) FMA $20 \mathrm{~g} / \mathrm{rpn}+$ kompos $100 \%$. Peubah yang diamati adalah kandungan NDF, ADF, hemiselulosa, selulosa dan lignin, Hasil penelitian menunjukkan bahwa perlakuan berpengaruh nyata terhadap semua peubah yang diamati.
\end{abstract}

Kata kunci: Hymenache amplexicaulis (Rudge) Nees, fraksi serat, fungi mikoriza arbuskula, pupuk organik

\section{ABSTRACT}

Arbuscular mycorrhizal fungi (FMA) may help the plant for the provision and absorption of $\mathrm{P}$ element where as the availability is low in acid soils. Organic fertilizers will affect to the physical, chemical and biological properties of the soil. The purpose of this study was to find out and prove that improvements in ultisol fertility by giving FMA and organic fertilizer will affect the fiber content of kumpai grass. The experiment used a Randomized Block Design with five treatments and 4 replications. The treatments were consisted of: 1) FMA o g / pot + organic fertilizer o\%, 2) FMA $20 \mathrm{~g} /$ pot + organic fertilizer 50\% cow dung, 3) FMA $20 \mathrm{~g} /$ po $\mathrm{t}+100 \%$ cow manure, 4) FMA $20 \mathrm{~g} /$ pot $+50 \%$ compost, and 5) FMA $20 \mathrm{~g} /$ pot $+100 \%$ compost. The observed variables were NDF, ADF, hemicellulose, cellulose and lignin content. The results showed that the treatment had significant effect on all observed variables.

Keywords: Hymenache amplexicaulis (Rudge) Nees, fiber fraction, arbuscular mycorrhizal fungi, organic fertilizer

\section{PENDAHULUAN}

Hijauan pakan di daerah tropis memiliki tingkat kandungan fraksi serat yang tinggi. Nutrien tersebut merupakan faktor utama penyebab rendahnya kemampuan ternak untuk mengkonsumsi hijauan dan mempengaruhi daya cerna serta laju alir partikel pakan hijauan. NDF mewakili kandungan dinding selyang terdiri dari lignin,selulosa dan hemiselulosa. Selulosa adalah komponen utama dari dinding sel tanaman dan merupakan produk utama dari proses fotosintesis yang menyebabkan pengayuan atau kuatnya suatu tanaman. Hemiselulosa adalah senyawa kimia yang merupakan satu grup dengan selulosa namun dengan berat molekul yang lebih rendah (Kusnandar, 2010). Hemiselulosa mengikat lembaran serat selulosa membentuk mikro fibril yang meningkatkan stabilitas dinding sel. Lignin merupakan salah satu zat komponen penyusun tumbuhan, komposisi penyusunan ini berbeda-beda tergantung jenisnya.

Untuk memperluas penganekaragaman hijauan pakan daerah tropis, maka hijauan lokal perlu dikembangkan guna menunjang kebutuhan hijauan bagi ternak ruminansia yang berbasis sumber daya lokal. Beberapa jenis hijauan lokal menunjukkan kelebihan dibanding introduksi, salah satunya adalah rumput lokal kumpai (Hymenachne amplexicaulis (Rudge) Ness. Lahan untuk penanaman hijauan semakin berkurang, disebabkan karena dimanfaatkan 
untuk menanam tanaman pangan, perkebunan serta berbagai keperluan non pertanian. Salah satu upaya adalah melalui pemanfaatan tanah marginal ultisol yang masih cukup luas (Mulyani dan Lubis, 2008; Jamarun dan Zain, 2012).

Fungi mikoriza arbuskula menginfeksi sistem perakaran tanaman inang dengan membentuk jalinan hifa secara intensif, sehingga tanaman mampu meningkatkan penyerapan hara dan air, namun yang lebih utama ditingkatkannya adalah unsur hara fosfat (Beinroth, 2001, Kanno dkk., 2006). Pupuk organik adalah pupuk yang sebagian besar atau seluruhnya terdiri atas bahan organik untuk memperbaiki sifat fisik, kimia dan biologi tanah (Simanungkalit $d k k$., 2006). Pupuk organik memiliki kandungan hara yang lengkap, bahkan didalam pupuk organik juga terdapat senyawa organik lain yang bermanfaat bagi tanaman, seperti asam humik, asam fulfat dan senyawa-senyawa organik lainnya namun kandungannya rendah (Sumarsono dkk., 2006).

Penelitian ini bertujuan untuk menemukan, mendapatkan dan membuktikan pengaruh fungi mikoriza arbuskula dan pupuk organik terhadap kandungan fraksi serat rumput kumpai pada ultisol.

\section{MATERI DAN METODE}

Penelitian dilakukan di Kecamatan Kotabaru Kota Jambi selama 5 (lima) bulan. Dilanjutkan dengan analisis fraksi serat hijauan (NDF, ADF, Hemiselulosa, Selulosa dan Lignin) di laboratorium Nutrisi Ruminansia Fakultas Peternakan Universitas Andalas.

Bahan yang digunakan adalah rumput kumpai diperoleh dari Kabupaten Muaro Jambi Provinsi Jambi. FMA jenis multiple spora dengan merk dagang Cemiko I yang terdiri dari (Glomus sp, Acaulospora sp dan Scutellospora sp,) diperoleh dari laboratorium Ilmu Tanah Fakultas Pertanian Universitas Andalas. Pupuk organik yang digunakan adalah pupuk organik kotoran sapi dan kompos. Sebagai pupuk dasar digunakan TSP, $\mathrm{KCl}, \mathrm{CO}\left(\mathrm{NH}_{2}\right)_{2}$. Peralatan yang digunakan adalah peralatan pengolah tanah, mistar, alat penyiram, kantong plastik, timbangan, polybag, dan peralatan laboratorium untuk analisa fraksi serat hijauan.

Percobaan ini menggunakan Rancangan Acak Kelompok dengan lima macam perlakuan dan 4 ulangan. Perlakuan sebagai berikut: 1) FMA o g/rpn + pupuk organik o\% ; 2) FMA $20 \mathrm{~g} / \mathrm{rpn}+$ pupuk organik kotoran sapi 50\%; 3) FMA $20 \mathrm{~g} / \mathrm{rpn}+$ pupuk organik kotoran sapi 100\%; 4) FMA $20 \mathrm{~g} / \mathrm{rpn}+$ kompos 50\%; DAN 50 FMA 20 g/rpn + kompos 100\%.

\section{Pelaksanaan}

Sebelum rumput ditanam terlebih dahulu dilakukan pengolahan tanah dengan cara memangkas habis tumbuhan liar/vegetasi penutup tanah. Selanjutnya pembuatan petak-petak percobaan dengan ukuran $1 \mathrm{~m} \times 2 \mathrm{~m}$, jarak antar blok $1 \mathrm{~m}$ dan antar petak 0,50 m. Sebagai pupuk dasar digunakan TSP (45\% $\mathrm{P}_{2} \mathrm{O}_{5}$ ) dengan dosis $150 \mathrm{~kg} \mathrm{P}_{2} \mathrm{O}_{5} /$ ha setara dengan 66,67 g TSP/petak); $\mathrm{KCl}\left(60 \% \mathrm{~K}_{2} \mathrm{O}\right)$ dengan dosis $100 \mathrm{~kg} \mathrm{~K} \mathrm{~K}_{2} \mathrm{O} /$ ha setara dengan $33,33 \mathrm{~g} \mathrm{KCl} /$ petak); Urea $(46 \% \mathrm{~N})$ dengan dosis $200 \mathrm{~kg} \mathrm{~N} / \mathrm{ha}$ setara dengan 88,82 g Urea/petak. Pupuk dasar TSP, KCl, dan pupuk organik diberikan secara bersamaan, dengan cara ditebar di tanah dalam petak percobaan, kemudian diaduk menggunakan alat garu agar lebih homogen, dan dibiarkan selama seminggu sampai saat penanaman. FMA diberikan dengan cara memasukkan pada setiap lubang tanam, diberikan bersamaan penanaman rumput. Bahan tanam berupa potongan batang dengan panjang lebih kurang $25 \mathrm{~cm}$ (terdiri dari 3 ruas dan 2 buku), untuk setiap lubang tanam ditanam tiga bahan tanam, dengan kedalaman \pm 8 $\mathrm{cm}$, dan jarak tanam 50 x $50 \mathrm{~cm}$. Untuk menentukan kandungan fraksi serat hijauan dengan metode Van Soest (Georing dan Van Soest, 1970 dan Van Soest dan Robertson, 1980.)

Peubah yang diamati meliputi kandungan NDF, ADF, hemisellulosa, sellulosa dan lignin. Pengolahan data dilakukan menggunakan analisis keragaman untuk mengetahui pengaruh perlakuan terhadap peubah yang diamati. Perlakuan yang berpengaruh nyata dilanjutkan dengan uji jarak berganda Duncan.

\section{HASIL DAN PEMBAHASAN}

\section{Neutral Detergent Fibre (NDF)}

Kandungan NDF yang tinggi merupakan salah satu faktor penyebab rendahnya kemampuan ternak untuk mengkonsumsi hijauan pakan, dan mempengaruhi daya cerna. Kandungan NDF rumput kumpai yang diperoleh dalam penelitian ini dicantumkan Tabel 1.

Tabel 1 Pengaruh Kombinasi Perlakuan Fungi Mikoriza Arbuskula dengan Pupuk Organik terhadap Kandungan NDF (\%)

\begin{tabular}{lc}
\hline \multicolumn{1}{c}{ Kombinasi Perlakuan } & NDF \\
\hline FMA 0 g/rpn dgn Pupuk Organik 0\% & 59,35 a \\
FMA 20 g/rpn dgn Pupuk Organik Kotoran Sapi 100\% & 51,25 e \\
FMA 20 g/rpn dgn Kompos 100\% & 52,90 d \\
FMA 20 g/rpn dgn Pupuk Organik Kotoran Sapi 50\% & 54,52 c \\
FMA 20 g/rpn dgn Kompos 50\% & 57,10 b \\
\hline
\end{tabular}

Keterangan: Pengaruh Kombinasi Perlakuan Fungi Mikoriza Arbuskula dengan Pupuk Organik terhadap Kandungan NDF (\%)

Hasil analisis ragam memperlihatkan bahwa perlakuan berpengaruh sangat nyata $(\mathrm{P}<\mathrm{O}, \mathrm{O1})$ terhadap kandungan NDF. Perbedaan kandungan 
NDF ini, disebabkan adanya respon pertumbuhan tanaman pada tiap perlakuan memiliki kemampuan yang berbeda dalam absorpsi unsur hara, meskipun interval pemotongan yang dilakukan seragam. Penurunan kandunganNDF, juga erat hubungannya dengan kandungan lignin hijauan. Crampton dan Haris(1969) bahwa penurunan kandungan NDF disebabkan karena meningkatnya lignin pada tanaman, mengakibatkan menurunnya hemiselulosa. Sutardi (1980) lignin merupakan komponen serat kasar yang terdapat sebagian dalam dinding sel dari bagian batang tumbuhan, dan tidak mudah dicerna. Menurunnya kandungan NDF juga dapat terjadi selama proses fermentasi, karena adanya mikroba yang mampu mencerna komponen dinding sel.

\section{Acid Detergent Fibre (ADF)}

Pengukuran ADF diperlukan untuk menilai kualitas hijauan makanan ternak. Kandungan ADF rumput kumpai yang dihasilkan disajikan pada Tabel 2.

Tabel 2. Pengaruh Kombinasi Perlakuan Fungi Mikoriza Arbuskula dengan Pupuk Organik terhadap Kandungan ADF (\%)

\begin{tabular}{lc}
\hline \multicolumn{1}{c}{ Kombinasi Perlakuan } & ADF \\
\hline FMA 0 g/rpn dgn Pupuk Organik 0\% & 35,30 a \\
FMA 20 g/rpn dgn Pupuk Organik Kotoran Sapi 100\% & 25,48 e \\
FMA 20 g/rpn dgn Kompos 100\% & 27,86 d \\
FMA 20 g/rpn dgn Pupuk Organik Kotoran Sapi 50\% & $30,28 \mathrm{c}$ \\
FMA 20 g/rpn dgn kompos 50\% & $32,96 \mathrm{~b}$ \\
\hline
\end{tabular}

Keterangan : Angka-angka pada lajur yang sama diikuti huruf kecil berbeda, adalah berbeda nyata pada Uji DNMRT taraf 0,05.

Hasil analisis ragam memperlihatkan bahwa perlakuan berpengaruh sangat nyata $(\mathrm{P}<\mathrm{O}, \mathrm{O1})$ terhadap kandungan ADF. Penurunan kandungan ADF diakibatkan oleh adanya mikroorganisme yang melakukan perubahan sehingga memperbaiki mutu pakan, diantaranya mampu menurunkan kandungan ADF. Menurut Winarno dan Fardiaz (1980) proses fermentasi bahan pakan oleh mikroorganisme menyebabkan perubahan yang menguntungkan seperti memperbaiki mutu bahan pakan, baik dari aspek gizi maupun daya cerna. Vansoest (1994) terdapat hubungan antara ADF dan lignin dengan manfaat dari hijauan. Bila kandungan ADF dalam hijauan tinggi, terutama lignin, maka koefisien cerna bahan makanan tersebut rendah. Di lain pihak, kandungan unsur nitrogen dalam pupuk organik, dapat meningkatkan bagian protoplasma dibanding dinding sel, meningkatkan kandungan air protoplasma, dan mengurangi kalsium. Oleh karena itu, peningkatan ukuran sel dan penambahan ketebalan dinding sel menyebabkan daun dan batang tanaman menjadi lebih sekulen (Kaunang, 2006).

\section{Lignin}

Lignin terakumulasi pada batang tumbuhan, berfungsi sebagai bahan pengikat komponen penyusun lainnya membentuk struktur yang kuat/kokoh. Kandungan lignin yang diperoleh dalam penelitian ini dicantumkan pada Tabel 3 .

Tabel 3. Pengaruh Kombinasi Perlakuan Fungi Mikoriza Arbuskula dengan Pupuk Organik Terhadap Kandungan Lignin (\%)

\begin{tabular}{ll}
\hline \multicolumn{1}{c}{ Kombinasi Perlakuan } & Lignin \\
\hline FMA 0 g/rpn dgn Pupuk Organik 0\% & $6,85 \mathrm{a}$ \\
FMA 20 g/rpn dgn Pupuk Organik Kotoran Sapi 100\% & $5,13 \mathrm{e}$ \\
FMA 20 g/rpn dgn Kompos 100\% & $5,32 \mathrm{~d}$ \\
FMA 20 g/rpn dgn Pupuk Organik Kotoran Sapi 50\% & $5,61 \mathrm{c}$ \\
FMA 20 g/rpn dgn Kompos 50\% & $5,79 \mathrm{~b}$ \\
\hline
\end{tabular}

Keterangan: Angka-angka pada lajur yang sama diikuti huruf kecil berbeda, adalah berbeda nyata pada Uji DNMRT taraf 0,05.

Hasil analisis ragam memperlihatkan bahwa perlakuan berpengaruh sangat nyata $(\mathrm{P}<\mathrm{O}, \mathrm{O1})$ terhadap kandungan lignin. Perbedaan kandungan lignin tiap perlakuan, disebabkan adanya perbedaan struktur dan dinding sel. Tanaman bermikoriza pada umumnya tumbuh lebih subur, daun lebih banyak, batang lebih lunak/lebih sekulen diabanding tanpa mikoriza. Faktor lain yang juga menyebabkan perbedaan kandungan lignin adalah kekahatan senyawa protein. Kekahatan senyawa protein dapat menyebabkan kenaikan nisbah $\mathrm{C} / \mathrm{N}$, dan kelebihan karbohidrat ini dapat menyebabkan membran sel menebal, sehingga dapat menyebabkan meningkatnya jaringan berlignin (Kaunang, 2006). Sutardi (1980) lignin merupakan bagian atau komponen dari serat yang terdapat sebagian dalam dinding sel dari tanaman. Hasil penelitian Mansyur et al., (2006) kandungan lignin rumput Signal (Brachiaria decumbens) interval pemotongan 40 hari juga menunjukkan kandungan lignin relatif masih rendah.

\section{Sellulosa}

Sellulosa adalah zat penyusun tanaman yang terdapat pada struktur sel.Kadar selulosa pada tanaman hijauan pakan yang muda mencapai $40 \%$ dari bahan kering. Namun demikian, bila hijauan makin tua maka proporsi selulosa makin bertambah. Kandungan sellulosa yang dihasilkan disajikan pada Tabel 4.

Hasil analisis ragam memperlihatkan bahwa perlakuan berpengaruh sangat nyata $(\mathrm{P}<0,01)$ terhadap kandungan sellulosa. Perbedaan kandungan sellulosa ini, berhubungan dengan kemampuan tanaman dalam absorpsi unsur hara untuk pembentukan sel tanaman, karena selulosa merupakan komponen utama penyusun dinding sel tanaman. Bila hijauan makin tua, maka perbandingan/proporsi selulosa dan hemisellulosa makin bertambah (Tillman et al., 
Tabel 4. Pengaruh Kombinasi Perlakuan Fungi Mikoriza Arbuskula dengan Pupuk Organik terhadap Kandungan Sellulosa (\%)

\begin{tabular}{lc}
\hline \multicolumn{1}{c}{ Kombinasi Perlakuan } & Selulosa \\
\hline FMA 0 g/rpn dgn Pupuk Organik 0\% & 30,52 e \\
FMA 20 g/rpn dgn Pupuk Organik Kotoran Sapi 100\% & 39,63 a \\
FMA 20 g/rpn dgn Kompos 100\% & 36,70 b \\
FMA 20 g/rpn dgn Pupuk Organik Kotoran Sapi 50\% & 34,50 c \\
FMA 20 g/rpn dgn Kompos 50\% & 33,10 d \\
\hline
\end{tabular}

Keterangan: Angka-angka pada lajur yang sama diikuti huruf kecil berbeda adalah berbeda nyata pada Uji DMRT taraf 0,05.

1989). Sellulosa merupakan polimer linier dari $\beta$-Dglukosa yang dihubungkan satu sama lain dengan ikatan glikosidikb-(1,4). Namun demikian, penurunan kandungan selullosa juga dapat terjadi selama proses fermentasi disebabkan karena adanya enzim-enzim pencerna serat. Kandungan sellulosa pada dinding sel tanaman sekitar 35-50\%dari berat kering tanaman (Lyndet al., 2002).

\section{Hemisellulosa}

Hemisellulosa mengikat lembaran serat selulosa membentuk mikro fibril yang meningkatkan stabilitas dinding sel, juga berikatan silang dengan lignin membentuk jaringan kompleks dan memberikan struktur yangkuat. Kandungan hemiselulosa yang dihasilkan dicantumkan pada Tabel 5 .

Tabel 5. Pengaruh Kombinasi Perlakuan Fungi Mikoriza Arbuskula dengan Pupuk Organik Terhadap Kandungan Hemisellulosa (\%)

\begin{tabular}{lc}
\hline \multicolumn{1}{c}{ Kombinasi Perlakuan } & Hemiselulosa \\
\hline FMA 0 g/rpn dgn Pupuk Organik 0\% & 24,05 e \\
FMA 20 g/rpn dgn Pupuk Organik Kotoran Sapi 100\% & 25,77 a \\
FMA 20 g/rpn dgn Kompos 100\% & 25,14 b \\
FMA 20 g/rpn dgn Pupuk Organik Kotoran Sapi 50\% & 24,24 c \\
FMA 20 g/rpn dgn Kompos 50\% & 24,14 d
\end{tabular}

Keterangan: Angka-angka pada lajur yang sama diikuti huruf kecil berbeda, adalah berbeda nyata pada Uji DNMRT taraf 0,05.

Hasil analisis ragam memperlihatkan bahwa perlakuan berpengaruh sangat nyata $(\mathrm{P}<0,01)$ terhadap kandungan hemisellulosa. Perbedaan ini disebabkan oleh kemampuan dari tanaman dalam menyerap unsur hara untuk pertumbuhan dan perkembangan tanaman, terutama dalam pembentukan sel tanaman. Kemampuan tanaman bermikoriza dalam menyerap unsur hara lebih besar dari tanpa mikoriza. Namun demikian, penyerapan unsur hara dan air oleh tanaman bermikoriza semakin meningkat dengan peningkatan dosis pupuk organik. Hal ini, disebabkan karena pupuk organik merupakan sumber nutrisi dan energi bagi pertumbuhan dan perkembangan mikoriza.

\section{SIMPULAN}

Kombinasi perlakuan FMA $20 \mathrm{~g} /$ pot dengan pupuk organik kotoran sapi $100 \%$ menghasilkan kandungan $\mathrm{NDF}, \mathrm{ADF}$ dan lignin lebih rendah, serta menghasilkan kandungan sellulosa dan hemisellulosa lebih tinggi dibandingkan dengan kombinasi perlakuan lainnya.

\section{DAFTAR PUSTAKA}

Mulyani, A. dan I. Lubis. 2008. Potensi Sumber Daya Lahan dan Optimalisasi Pengembangan Komoditas Penghasil Bioenergi di Indonesia.

Beinroth, F. H. 2001. Land Resources for Forage Production in the Tropics In Sotomayor - Rios A. Pitman Wd (eds) Tropical Forage Plants Development and Use CRC Press. Pp3-15.

Georing, H. K., and P. J. Van Soest. 1970. Forage Fiber Analysis. Agriculture Handbook. USDA. Washington DC. USA. 379: 187-198.

Jamarun, N. dan M. Zain. 2012. Dasar Nutrisi Ruminansia. Penerbit Jasa Surya Padang.

Kanno, T., M., Y. Saito, M. Ando, C.M. Macedo, T. Nakamura and C.H.B. Miranda. 2006. Importance of indigenous arbuscular mycorrhizal for growth and phosphourus uptake in tropical forage grasses growing on an acid soil, infertile soil from the Brazilian savannas. Trop. Grasslands. 40:94-101.

Kusnandar, F. 2010. Mengenal Serat Pangan. Departemen Ilmu dan Teknologi Pangan Institut Pertanian Bogor.

Lynd L. R., P. J. W.H. Weimer, VanZy, W. Handi. S.Pretorius.2002. Microbial cellulose utilization: fundamentals and biotechnology. Microbiol. Mol. Biol. Rev. 66(3):506-577.

Mansyur, N. P. Indriani., T. Dhalika dan A. R. Tarmidi. 2006. Pengaruh kedewasaan terhadap isi sel, dan fraksi serat rumput Signal (Brachiaria decumbens) yang ditanam di bawah naungan perkebunan pisang. Laporan Penelitian. Fakultas Peternakan Universitas Padjadjaran Bandung.

Simanungkalit, M. D. R., D. R. Suriadikarta, R. Saraswati, D. Setyorii dan W. Hartatik. 2006. Pupuk organik dan pupuk hayati (organic fertilizer and biofertilizer). Balai Besar Litbang Sumberdaya Lahan Pertanian, Badan Penelitian Dan Pengembangan Pertanian Bogor.

Sumarsono, S. Anwar dan S. Budiyanto. 2006. Peranan pupuk organik untuk keberhasilan pertumbuhan tanaman pakan rumput poliploid pada tanah masam dan salin. Laporan Penelitian. Fakultas Peternakan Universitas Diponegoro, Semarang.

Syafna. 2010. Efek Pemupukan Nitrogen dan Interval Pemotongan terhadap pertumbuhan dan produksi rumput lokal Kumpai (Hymenachne 
amplexicaulis (Rudge) Nees.). Majalah Ilmiah Percikan Bandung. Edisi Mei 2010. ISSN :08548986. Hal: 45-50.

Van Soest. P. J., and Robertson, J. B. 1980. System of analysis for evaluating fibrous feeds. In: Standardization of Analytical Methodology in Feeds (Pigden, W.J., Balch, C.C and Graham, M., eds), pp.49-6o. International Research Development Center, Ottawa, Canada. 